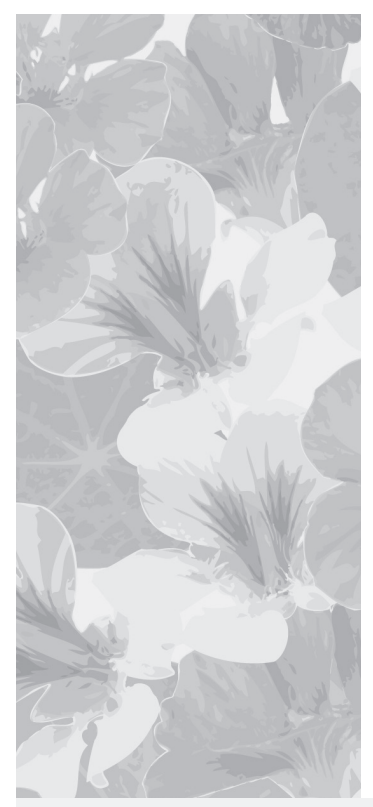

\title{
Kosmetyki do cery trądzikowej dostępne w aptekach: Analiza deklarowanych składników aktywnych oraz substancji potencjalnie niebezpiecznych
}

\author{
Anti-acne cosmetics available from chemists' shops: An analysis of active \\ ingredients and potentially harmful substances
}

Sabina Zofia Rzeźnik, Katarzyna Kordus, Radosław Śpiewak

Zakład Dermatologii Doświadczalnej i Kosmetologii, Wydział Farmaceutyczny

Uniwersytet Jagielloński Collegium Medicum, Kraków

Estetol Med Kosmetol 2012; 2(3): 77-82

DOI: http://dx.doi.org/10.14320/EMK.2012.016

\section{Streszczenie}

Osoby z problemami trądzikowymi kupując preparaty kosmetyczne w aptekach liczą, że ich skuteczność i bezpieczeństwo stosowania są większe niż w przypadku typowych kosmetyków drogeryjnych. Cel: Analiza składu dostępnych w aptekach kosmetyków do cery trądzikowej pod kątem występowania w nich substancji aktywnych oraz „problematycznych”, czyli stanowiących zagrożenie dla zdrowia (alergia, podrażnienie). Materiat i metody: Kosmetyki zakwalifikowano do analiz na podstawie występowania w ich nazwie lub wskazaniach do stosowania stów „trądzik”, „przeciwtrądzikowy”, „zaskórniki”, „pryszcze”, „wągry”, „pory”, „preparat antybakteryjny”. Deklarowany przez producentów skład produktów poddano analizie pod kątem obecności składników aktywnych oraz substancji potencjalnie niebezpiecznych („problematycznych”). Za substancje aktywne uznano te, które wykazują dziatanie keratolityczne bakteriostatyczne, seboregulujące oraz przeciwzapalne. Substancje „problematyczne” wyodrębniono na podstawie Aneksów III i VI do Dyrektywy Kosmetycznej 76/768/EWG udostępnionych w europejskiej bazie danych Coslng (2008). Wyniki: W 50 losowych produktach zidentyfikowano 394 unikalne substancje (100\%), w tym 70 (18\%) substancji sklasyfikowano jako aktywne, a 59 (15\%) jako „problematyczne”. Najczęściej występującą w produktach substancją aktywną był kwas salicylowy (obecny w $34 \%$ analizowanych produktów), a następnie alantoina (32\%) oraz piroglutaminian cynku (30\%). Najczęściej występującymi w analizowanych kosmetykach substancjami „problematycznymi” okazały się konserwanty fenoksyetanol (40\%) oraz metyloparaben (38\%). Składniki aktywne przeciw wszystkim znanym elementom patologii trądziku zawierało tylko $36 \%$ analizowanych produktów. Wnioski: Zaledwie jeden na trzy apteczne kosmetyki przeciwtrądzikowe zawiera składniki aktywne przeciw wszystkim elementom trądziku, natomiast prawie wszystkie produkty zawierają składniki „problematyczne” mogące wywoływać uczulenia lub podrażnienia.

Stowa kluczowe: kosmetyki przeciwtrądzikowe, trądzik pospolity, substancja aktywna, substancja niebezpieczna

\begin{abstract}
People who buy anti-acne cosmetics in chemists' shops seem to hope that the effectiveness and safety of such preparations would be higher than cosmetics available from cosmetics stores. Aim: Analysis of the composition of anti-acne cosmetics available at chemist's with regard to the presence of active ingredients and 'problematic' substances, i.e. substances with potentially harmful effects (allergy, irritation). Material and methods: Cosmetics offered in chemists' shops were included into this research based on the occurrence of the following words: 'acne', 'blackhead', 'pimples', 'comedones', 'skin pores', 'anti-bacterial preparation' in their trade names or identification (front label), or recommendations for use (back label). The compositions of the products as declared on the label were analyzed for the presence of active components and 'problematic' substances. As active substances were considered those with known keratolytic, bacteriostatic, seboregulatory or anti-inflammatory properties. The 'problematic' substances were identified with reference to the Annexes to the Cosmetics Directive 76/768/EEC available from the CosIng database. Results: In 50 random products included into the present study, 394 unique ingredients were identified (100\%), of which $70(18 \%)$ were categorized as active, and 59 $(15 \%)$ as 'problematic' substances. Active substances most commonly present in the products were salicylic acid (present in $34 \%$ of analysed products), allantoin (32\%) and zinc PCA (30\%). The 'problematic' ingredients most widely used in the analysed products were the preservatives phenoxyethanol (40\%) and methylparaben (38\%). Only $36 \%$ of all analyzed products contained combinations of active ingredients directed against all known pathological elements of acne. Conclusions: Only one in three anti-acne cosmetics available from chemists' shops contain active ingredients against all key elements of acne pathology. On the other hand, almost all of such preparations contain 'problematic' ingredients which can cause allergy or irritancy.
\end{abstract}

Keywords: anti-acne cosmetics, acne vulgaris, active ingredients, hazardous substances

Copyright $\odot 2012$ the Authors (text) and Radostaw Śpiewak (layout \& journal compilation). All rights reserved.

Trądzik pospolity (trądzik zwyczajny, acne vulgaris) to choroba skóry, która dotyczy nie tylko osób w wieku dojrzewania. Problem ten jest zarówno spotykany u niemowląt, jak i u ludzi dorosłych. Jest zaburzeniem funkcji gruczołów łojowych okolic twarzy i tułowia $[1,2]$. To dermatoza o niezwykle złożonej patogenezie, na którą składa się $[1,3,4]$ : 
- $\quad$ nieprawidłowe złuszczanie komórek ujść mieszków włosowych

- $\quad$ zaburzenia wydzielania androgenów

- obecność bakterii Propionibacterium acnes

- nadmierna produkcja sebum

- $\quad$ obecność mediatorów stanu zapalnego.

Skóra trądzikowa wymaga starannej pielęgnacji. Do tego celu przeznaczone są specjalistyczne produkty uzupełniające leczenie trądziku, charakteryzujące się [4]:

- $\quad$ łagodnym działaniem oczyszczającym, eliminującym efekt nasilonego łojotoku skóry

- właściwościami antykomedogennymi (przeciwdziałającymi zatykaniu porów skóry)

- $\quad$ brakiem interakcji z lekami przeciwtrądzikowymi

- $\quad$ właściwościami łagodzącymi, kojącymi działania niepożądane będące konsekwencją leczenia, np. suchość skóry

- $\quad$ kamuflażem kosmetycznym.

Sprzedaż kosmetyków przeciwtrądzikowych w aptece może sprawiać na nabywcach wrażenie, że mają do czynienia z produktami o cechach zbliżonych do leków, to jest bardziej skutecznych a zarazem bezpieczniejszych. Nasuwa się w tym kontekście pytanie, czy tak jest faktycznie.

\section{Cel}

Celem pracy była analiza składu sprzedawanych w aptece kosmetyków do cery trądzikowej pod kątem występowania w nich składników aktywnych oraz substancji potencjalnie niebezpiecznych.

\section{Materiat i metody}

Dane na temat składu analizowanych kosmetyków do cery trądzikowej zebrano w sześciu losowo wybranych aptekach. Wykonano dokumentację fotograficzną etykiet i składu 50 kosmetyków. Były to preparaty do demakijażu (10 produktów), toniki (10), preparaty punktowe (10), kremy (10), maski (10). Produkty do niniejszej analizy wybrano na podstawie występowania w nazwie lub opisie działania następujących słów kluczowych: „trądzik”, „przeciwtrądzikowy”, ,zaskórniki”, ,,pryszcze”, „wągry”, „,pory”, „niedoskonałości”, „preparat antybakteryjny". Następnie dokonano analizy każdego produktu, przeprowadzonej na podstawie składu INCI (International Nomenclature of Cosmetic Ingrediens/Międzynarodowe Nazewnictwo Składników Kosmetyków) znajdującego się na odwrocie opakowania. INCI jest sposobem zapisywania nazw substancji, które są wykorzystywane do produkcji kosmetyków [5]. System ten został stworzony przez organizację The Personal Care Products Council zrzeszającą producentów kosmetyków w USA oraz współgra on z ustaleniami organizacji producentów europejskich (The European Cosmetic, Toiletry, and Perfumery Association, COLIPA), a także japońskich (The Japan Cosmetic Industry Association) [6]. $\mathrm{W}$ celu analizy posłużono się europejską bazą danych CosIng (2008) powstałą na podstawie Decyzji 257/2007/ WE ustanawiającej wykaz i nazewnictwo składników kosmetyków, a także zawierającą informacje na temat substancji kosmetycznych oraz Leksykonem Surowców Kosmetycznych [7]. Składniki podzielono odpowiednio na rozpuszczalniki, substancje tonizujące, ochronne, nawilżające, antyperspiranty, przeciwosadowe, propelenty, substancje uplastyczniające, seboregulujące, wybielające, kojące, absorbery promieniowania UV, filtry UV, substancje pieniące, przeciwkorozyjne, uwadniające, buforujące, chelatujące, kontrolujące lepkość, kondycjonujące, emolienty, humektanty, zmętniające, ścierające, chłonne, przeciwzbrylające, wypełniające, wiążące, ściągające, maskujące, zwiększające pienienie, przeciwpienne, przeciwdrobnoustrojowe, surfaktanty, stabilizatory emulsji, substancje żelujące, antystatyczne, czyszczące, antyoksydacyjne, natłuszczające, perfumujące, konserwujące, koloryzujące, stabilizujące, wygładzające, przeciwłupieżowe, keratolityczne, denaturujące oraz deodorujące.

Za główne elementy patogenezy trądziku uznaje się nieprawidłowe rogowacenie, zaburzenia wydzielania androgenów, obecność bakterii Propionibacterium acnes, łojotok oraz obecność mediatorów stanu zapalnego [3], dlatego podczas niniejszej analizy produktów przeciwtrądzikowych za aktywne składniki uznane zostały substancje o działaniu keratolitycznym, bakteriostatycznym, seboregulującym oraz przeciwzapalnym. Skład kosmetyków analizowano ponadto pod kątem zawartości substancji niebezpiecznych zakazanych w kosmetykach oraz substancji dopuszczalnych do stosowania w kosmetykach w ograniczonym stężeniu. Wykorzystano do tego listę składników niedozwolonych (List of substances prohibited in cosmetics product) oraz dozwolonych do stosowania z ograniczeniami (List of substances which cosmetic products must not contain except subject to the restrictions laid down), zawartych w Aneksach do Dyrektywy Kosmetycznej 76/768/EWG dostępnych w europejskiej bazie danych CosIng. W celu dokładniejszej weryfikacji posłużono się ponadto dostępnymi wykazami filtrów UV, konserwantów oraz barwników dopuszczalnych do stosowania w kosmetykach (List of UV filters allowed in cosmetic products, List of preservatives allowed in cosmetic products, List of colorants allowed in cosmetics products) również dostępnych w bazie danych CosIng. W dalszej kolejności obliczono, w jakim odsetku analizowanych preparatów występowały będące przedmiotem niniejszego badania składniki aktywne oraz substancje ,problematyczne".

Za bardziej skuteczne preparaty uznano arbitralnie te, które zawierały większą liczbę składników aktywnych, 
a za bardziej „niebezpieczne” preparaty zawierające więcej składników ,problematycznych”. W celu oceny związku pomiędzy aktywnością a bezpieczeństwem produktów przeprowadzono analizę korelacji między ilością składników aktywnych i ,problematycznych” w każdym produkcie. Zastosowano współczynnik korelacji liniowej Pearsona, oznaczony symbolem rxy, przyjmujący wartości z przedziału [-1,1]. Przyjęto następującą skalę: $r x y=0$ - zmienne nie są skorelowane, $0<$ r $x y<0,1$ - korelacja nikła, $0,1 \leq \mathrm{r} x y<0,3$ - korelacja słaba, $0,3 \leq \mathrm{r} x y<0,5$ - korelacja przeciętna, $0,5 \leq \mathrm{r} x y$ $<0,7$ - korelacja wysoka, $0,7 \leq \mathrm{r} x y<0,9$ - korelacja bardzo wysoka, $0,9 \leq \mathrm{r} x y<1$ - korelacja prawie pełna.

\section{Wyniki}

W 50 losowych produktach zidentyfikowano 394 unikalne substancje (100\%), z których 70 (17,8\%) sklasyfikowano jako aktywne, czyli wpływające korzystnie na poszczególne elementy patomechanizmu trądziku. Spośród zidentyfikowanych składników, 59 (15,0\%) było dopuszczone do stosowania z ograniczeniem, wśród nich 28 (7,1\%) konserwantów i 11 (2,8\%) substancji zapachowych. Producenci kosmetyków do pielęgnacji skóry z trądzikiem najczęściej wykorzystywali właściwości kwasu salicylowego, który był obecny w 34\% analizowanych produktów, dość popularne były substancje naturalne, na przykład sok z liści aloesu dodany do $12 \%$ analizowanych produktów (tabela 1 ). W deklarowanym składzie analizowanych produktów nie znaleziono substancji zakazanych (List of substances prohibited in cosmetics product), natomiast stwierdzono powszechną obecność substancji dozwolonych do stosowania z ograniczeniami (List of substances which cosmetic products must not contain except subject to the restrictions laid down), a także obecność substancji znajdującej się w wykazach filtrów UV (List of UV filters allowed in cosmetic products), konserwantów (List of preservatives allowed in cosmetic products) oraz barwników (List of colorants allowed in cosmetics products) dozwolonych do stosowania w ograniczonych stężeniach lub tylko w określonych rodzajach kosmetyków, zgodnie z wymienionymi aneksami do Dyrektywy Kosmetycznej 76/768/WE. „Problematycznym” konserwantem najczęściej spotykanym w analizowanych produktach był fenoksyetanol, obecny w $40 \%$ analizowanych produktów (tabela 2).
Tabela 1. Występowanie substancji aktywnych w analizowanych kosmetykach przeciwtrądzikowych

\begin{tabular}{|c|c|c|c|c|}
\hline Lp. & $\begin{array}{l}\text { Substancja aktywna } \\
\text { (Nazwa INCI) }\end{array}$ & $\begin{array}{l}\text { Substancja aktywna } \\
\text { (Nazwa polska) }\end{array}$ & $\mathbf{n}$ & $\%$ \\
\hline 1. & Salicylic acid & Kwas salicylowy & 17 & 34 \\
\hline 2. & Allantoin & Alantoina & 16 & 32 \\
\hline 3. & Zinc PCA & Piroglutaminian cynku & 15 & 30 \\
\hline 4. & Alcohol denat. & Alkohol denaturowany & 12 & 24 \\
\hline 5. & Citric acid & Kwas cytrynowy & 10 & 20 \\
\hline 6. & Panthenol & Pantenol & 10 & 20 \\
\hline 7. & Biotin & Biotyna & 9 & 18 \\
\hline 8. & Triclosan & Triklosan & 9 & 18 \\
\hline 9. & Zinc gluconate & Glukonian cynku & 9 & 18 \\
\hline 10. & Lactic acid & Kwas mlekowy & 7 & 14 \\
\hline 11. & Niacinamide & Witamina PP & 7 & 14 \\
\hline 12. & Aloe barbadensis leaf juice & $\begin{array}{l}\text { Sok z liści aloesu zwyczaj- } \\
\text { nego }\end{array}$ & 6 & 12 \\
\hline 13. & $\begin{array}{l}\text { Arctium majus (burdock) } \\
\text { extract }\end{array}$ & Wyciąg z łopianu większego & 6 & 10 \\
\hline 14. & Chlorphenesin & Chlorofenezyna & 5 & 10 \\
\hline 15. & $\begin{array}{l}\text { Melaleuca alternifolia (tea } \\
\text { tree) oil }\end{array}$ & $\begin{array}{l}\text { Olejek z drzewa herbacia- } \\
\text { nego }\end{array}$ & 5 & 10 \\
\hline 16. & Cetrimonium bromide & $\begin{array}{l}\text { Bromek cetylotrójmetylo- } \\
\text { aminowy }\end{array}$ & 4 & 8 \\
\hline 17. & $\begin{array}{l}\text { Tamarindus indica (tamarind) } \\
\text { extract }\end{array}$ & $\begin{array}{l}\text { Wyciąg z tamaryndowca } \\
\text { indyjskiego }\end{array}$ & 4 & 8 \\
\hline 18. & Tocopheryl acetate & Octan tokoferolu & 4 & 8 \\
\hline 19. & Ammonium glycyrrhizate & Lukrecja gładka & 3 & 6 \\
\hline 20. & Ascorbyl palmitate & Palmitynian askorbylu & 3 & 6 \\
\hline 21. & Azelaic acid & Kwas azelainowy & 3 & 6 \\
\hline 22. & Bisabolol & Bisabolol & 3 & 6 \\
\hline 23. & $\begin{array}{l}\text { Cinnamomum zeylanicum } \\
\text { bark extract }\end{array}$ & $\begin{array}{l}\text { Wyciąg z kory cynamonowca } \\
\text { cejlońskiego }\end{array}$ & 3 & 6 \\
\hline 24. & $\begin{array}{l}\text { Epilobium angustifolium } \\
\text { flower/leaf/steam extract }\end{array}$ & $\begin{array}{l}\text { Wyciąg parowy z kwiatów/ } \\
\text { liści wierzbówki kiprzycy }\end{array}$ & 3 & 6 \\
\hline 25. & Faex extract & Wyciąg z drożdży & 3 & 6 \\
\hline 26. & $\begin{array}{l}\text { Aesculus hippocastanum } \\
\text { extract }\end{array}$ & $\begin{array}{l}\text { Wyciąg z kasztanowca } \\
\text { zwyczajnego }\end{array}$ & 2 & 4 \\
\hline 27. & C12-15 Alkyl benzoate & $\begin{array}{l}\text { Ester kwasu mlekowego } \\
\text { i alkoholi thuszczowych } \\
\text { C12-15 }\end{array}$ & 2 & 4 \\
\hline 28. & $\begin{array}{l}\text { Chamomilla recutita flower } \\
\text { extract }\end{array}$ & $\begin{array}{l}\text { Wyciąg z kwiatów rumianku } \\
\text { pospolitego }\end{array}$ & 2 & 4 \\
\hline 29. & $\begin{array}{l}\text { Citrus medica limonum } \\
\text { (lemon) fruit extract }\end{array}$ & Wyciąg z owoców cytryny & 2 & 4 \\
\hline 30. & Commiphora myrrha extract & Wyciąg z balsamowca mirra & 2 & 4 \\
\hline 31. & $\begin{array}{l}\text { Hamamelis virginiana (witch } \\
\text { hazel) water }\end{array}$ & $\begin{array}{l}\text { Hydrolat z liści oczaru } \\
\text { wirginijskiego }\end{array}$ & 2 & 4 \\
\hline 32. & Mandelic acid & Kwas migdałowy & 2 & 4 \\
\hline 33. & Saccharomyces/zinc ferment & $\begin{array}{l}\text { Produkt fermentacji Saccha- } \\
\text { romyces w obecności cynku }\end{array}$ & 2 & 4 \\
\hline 34. & $\begin{array}{l}\text { Specially denatured (SD) alco- } \\
\text { hol 39-c (alcohol denat.) }\end{array}$ & Alkohol denaturowany 39-C & 2 & 4 \\
\hline 35. & Tocopherol & Tokoferol & 2 & 4 \\
\hline 36. & Zinc oxide & Tlenek cynku & 2 & 4 \\
\hline 37. & $\begin{array}{l}\text { Aesculus hippocastanum } \\
\text { flower extract }\end{array}$ & $\begin{array}{l}\text { Wyciąg z kwiatów kaszta- } \\
\text { nowca zwyczajnego }\end{array}$ & 1 & 2 \\
\hline 38. & Alcohol & Alkohol & 1 & 2 \\
\hline 39. & $\begin{array}{l}\text { Ananas sativus (pineapple) } \\
\text { fruit extract }\end{array}$ & Wyciąg z owoców ananasa & 1 & 2 \\
\hline 40. & Anthemis nobilis flower oil & $\begin{array}{l}\text { Olejek z kwiatów rumianu } \\
\text { rzymskiego }\end{array}$ & 1 & 2 \\
\hline 41. & Arctium lappa & Łopian większy & 1 & 2 \\
\hline
\end{tabular}




\begin{tabular}{|c|c|c|c|c|}
\hline 42. & $\begin{array}{l}\text { Candida bombicola/glucose/ } \\
\text { methyl rapeseedate ferment }\end{array}$ & $\begin{array}{l}\text { Produkt fermentacji Candida } \\
\text { bombicola w obecności } \\
\text { glukozy oraz metylu }\end{array}$ & 1 & 2 \\
\hline 43. & Chamomilla Recutita & Rumianek pospolity & 1 & 2 \\
\hline 44. & Chlorhexidine digluconate & Diglukonian chlorheksydyny & 1 & 2 \\
\hline 45. & $\begin{array}{l}\text { Citrus aurantium bergamia } \\
\text { (bergamot) fruit oil }\end{array}$ & $\begin{array}{l}\text { Wyciąg z owoców berga- } \\
\text { motki }\end{array}$ & 1 & 2 \\
\hline 46. & $\begin{array}{l}\text { Citrus aurantium dulcis } \\
\text { (orange) extract }\end{array}$ & $\begin{array}{l}\text { Wyciąg z drzewa słodkiej } \\
\text { pomarańczy }\end{array}$ & 1 & 2 \\
\hline 47. & $\begin{array}{l}\text { Citrus medica limonum } \\
\text { (lemon) peel extract }\end{array}$ & $\begin{array}{l}\text { Wyciąg peelingujący z } \\
\text { cytryny }\end{array}$ & 1 & 2 \\
\hline 48. & $\begin{array}{l}\text { Commiphora myrrha resin } \\
\text { extract }\end{array}$ & $\begin{array}{l}\text { Wyciąg z żywicy balsamowca } \\
\text { mirra }\end{array}$ & 1 & 2 \\
\hline 49. & $\begin{array}{l}\text { Cucumis sativus (cucumber) } \\
\text { fruit extract }\end{array}$ & $\begin{array}{l}\text { Wyciąg z owoców ogórka } \\
\text { siewnego }\end{array}$ & 1 & 2 \\
\hline 50. & Cupressus sempervires oil & $\begin{array}{l}\text { Olejek z cyprysa wiecznie } \\
\text { zielonego }\end{array}$ & 1 & 2 \\
\hline 51. & $\begin{array}{l}\text { Hamamelis virginiana (witch } \\
\text { hazel) extract }\end{array}$ & $\begin{array}{l}\text { Wyciąg z oczaru wirginij- } \\
\text { skiego }\end{array}$ & 1 & 2 \\
\hline 52. & $\begin{array}{l}\text { Lavandula augustifolia } \\
\text { (lavender) oil }\end{array}$ & $\begin{array}{l}\text { Olejek z lawendy wąsko- } \\
\text { listnej }\end{array}$ & 1 & 2 \\
\hline 53. & Lavandula flower water & Hydrolat z kwiatów lawendy & 1 & 2 \\
\hline 54. & $\begin{array}{l}\text { Linum usitatissimum (linseed) } \\
\text { seed extract }\end{array}$ & $\begin{array}{l}\text { Olej z nasion lnu zwyczaj- } \\
\text { nego }\end{array}$ & 1 & 2 \\
\hline 55. & $\begin{array}{l}\text { Lonicera caprifolium (honey- } \\
\text { suckle) flower extract }\end{array}$ & $\begin{array}{l}\text { Wyciąg z kwiatów wiciokrze- } \\
\text { wu przewiercienia }\end{array}$ & 1 & 2 \\
\hline 56. & $\begin{array}{l}\text { Lonicera japonica (honeysuc- } \\
\text { kle) flower extract }\end{array}$ & $\begin{array}{l}\text { Wyciąg z kwiatów wiciokrze- } \\
\text { wu japońskiego }\end{array}$ & 1 & 2 \\
\hline 57. & Portulaca oleracea extract & Wyciąg z portulaki pospolitej & 1 & 2 \\
\hline 58. & $\begin{array}{l}\text { Pyrus malus (apple) fruit } \\
\text { extract }\end{array}$ & Wyciąg z owoców jabłka & 1 & 2 \\
\hline 59. & Retinal & Retinal & 1 & 2 \\
\hline 60. & Retinyl palmitate & Palmitynian retinylu & 1 & 2 \\
\hline 61. & Rosmarinus officinalis extract & $\begin{array}{l}\text { Wyciąg z rozmarynu } \\
\text { lekarskiego }\end{array}$ & 1 & 2 \\
\hline 62. & $\begin{array}{l}\text { Santalum album (sandalwood) } \\
\text { oil }\end{array}$ & Olejek drzewa sandałowego & 1 & 2 \\
\hline 63. & Sebacic acid & Kwas sebacynowy & 1 & 2 \\
\hline 64. & Sulfur & Siarka & 1 & 2 \\
\hline 65. & Vaccinium myrtillus extrac & Wyciąg z borówki czarnej & 1 & 2 \\
\hline 66. & $\begin{array}{l}\text { Vitis vinifera (grape) fruit } \\
\text { extract }\end{array}$ & $\begin{array}{l}\text { Wyciąg z owoców winorośli } \\
\text { właściwej }\end{array}$ & 1 & 2 \\
\hline 67. & Vitis vinifera (grape) seed oil & $\begin{array}{l}\text { Olej z nasion winorośli } \\
\text { właściwej }\end{array}$ & 1 & 2 \\
\hline 68. & Zea mays (corn) starch & Skrobia kukurydziana & 1 & 2 \\
\hline 69. & Zinc lactate & Mleczan cynku & 1 & 2 \\
\hline 70. & Zinc sulfate & Siarczan cynku & 1 & 2 \\
\hline
\end{tabular}

Tabela 2. Występowanie substancji „problematycznych” w analizowanych kosmetykach przeciwtrądzikowych

\begin{tabular}{l|l|l|c|c} 
Lp. & $\begin{array}{c}\text { Substancja „problematyczna” } \\
\text { (Nazwa INCI) }\end{array}$ & $\begin{array}{c}\text { Substancja ,problematyczna” } \\
\text { (Nazwa polska) }\end{array}$ & $\mathbf{n}$ & $\%$ \\
\hline 1. & Phenoxyethanol & Fenoksyetanol & 20 & 40 \\
\hline 2. & Methylparaben & Metyloparaben & 19 & 38 \\
\hline 3. & Salicylic acid & Kwas salicylowy & 17 & 34 \\
\hline 4. & Zinc PCA & Piroglutaminian cynku & 15 & 30 \\
\hline 5. & Propylparaben & Propyloparaben & 14 & 28 \\
\hline 6. & Sodium hydroxide & Wodorotlenek sodu & 14 & 28 \\
\hline 7. & Triclosan & Triklosan & 9 & 18 \\
\hline 8. & Zinc gluconate & Glukonian cynku & 9 & 18 \\
\hline 9. & Sodium benzoate & Benzoesan sodu & 8 & 16 \\
\hline 10. & Ethylparaben & Etyloparaben & 7 & 14 \\
\hline 11. & Limonene & Limonen & 6 & 12 \\
\hline
\end{tabular}

\begin{tabular}{|c|c|c|c|c|}
\hline 12. & Piroctone olamine & Pirokton olaminy & 6 & 12 \\
\hline 13 & Butylparaben & Butyloparaben & 5 & 10 \\
\hline 14. & Chlorphenesin & Chlorofenezyna & 5 & 10 \\
\hline 15. & Linalool & Linalol & 5 & 10 \\
\hline 16. & Titanium dioxide (ci 77891) & Dwutlenek tytanu & 5 & 10 \\
\hline 17. & Triethanolamine & Trietanoloamina & 5 & 10 \\
\hline 18. & $\begin{array}{l}\text { 2-bromo-2-nitropropane- } \\
\text { 1,3-diol }\end{array}$ & $\begin{array}{l}\text { 2-bromo-2-nitropropano- } \\
\text { 1,3-diol }\end{array}$ & 4 & 8 \\
\hline 19. & Alpha-isomethyl ionone & $\begin{array}{l}\text { 3-metylo-4-(2,6,6-trimetylo- } \\
\text { 2-cykloheksen-1-ylo)-3-buten- } \\
\text { 2-on }\end{array}$ & 4 & 8 \\
\hline 20. & Cetrimonium bromide & $\begin{array}{l}\text { Bromek cetylotrójmetylo- } \\
\text { aminowy }\end{array}$ & 4 & 8 \\
\hline 21. & CI 42090 & CI 42090 (barwnik niebieski) & 4 & 8 \\
\hline 22. & Diazolidinyl urea & Diazolidynylan mocznika & 4 & 8 \\
\hline 23. & Benzoic acid & Kwas benzoesowy & 3 & 6 \\
\hline 24. & Benzyl alcohol & Alkohol benzylowy & 3 & 6 \\
\hline 25. & Citronellol & Cytronelol & 3 & 6 \\
\hline 26. & CI 77491 & CI 77491 (barwnik czerwony) & 3 & 6 \\
\hline 27. & CI 77492 & CI 77492 (barwnik żółty) & 3 & 6 \\
\hline 28. & DMDM hydantoin & $\begin{array}{l}\text { 1,3-bis(hydroksymetylo)- } \\
\text { 5,5-dimetyloimidazolidyno- } \\
\text { 2,4-dion }\end{array}$ & 3 & 6 \\
\hline 29. & Imidazolidinyl urea & Imidazolidyno mocznik & 3 & 6 \\
\hline 30. & Isobutylparaben & Isobutyloparaben & 3 & 6 \\
\hline 31. & Methylchloroisothiazolinone & Metylochloroizotiazolinon & 3 & 6 \\
\hline 32. & Methylisothiazolinone & Metyloizotiazolinon & 3 & 6 \\
\hline 33. & Potassium sorbate & Sorbinian potasu & 3 & 6 \\
\hline 34. & Sodium metabisulfite & Dwusiarczyn sodu & 3 & 6 \\
\hline 35. & $\begin{array}{l}\text { Butyl methoxydibenzoyl- } \\
\text { methane }\end{array}$ & $\begin{array}{l}\text { 1-(4-tert-butylofenylo)-3-(4- } \\
\text {-metoksyfenylo)propano-1,3- } \\
\text {-don }\end{array}$ & 2 & 4 \\
\hline 36. & CI 77499 (Iron Oxides) & CI 77499 (barwnik czarny) & 2 & 4 \\
\hline 37. & CI 19140 (Yellow 5) & CI 19140 (barwnik żółty) & 2 & 4 \\
\hline 38. & Coumarin & Kumaryna & 2 & 4 \\
\hline 39. & Dehydroacetic acid & Kwas dehydrooctowy & 2 & 4 \\
\hline 40. & Ethylhexyl methoxycinnamate & $\begin{array}{l}\text { 4-metoksycynamonian 2-ety- } \\
\text { loheksylu }\end{array}$ & 2 & 4 \\
\hline 41. & Octocrylene & Oktokrylen & 2 & 4 \\
\hline 42. & O-cymen-5-ol & 4-Izopropylo-m-krezol & 2 & 4 \\
\hline 43. & Polyacrylamide & Poliakrylamid & 2 & 4 \\
\hline 44. & Polyaminopropyl biguanide & Biguanid polyaminopropylu & 2 & 4 \\
\hline 45. & Saccharomyces/zinc ferment & $\begin{array}{l}\text { Produkt fermentacji Saccharo- } \\
\text { myces w obecności cynku }\end{array}$ & 2 & 4 \\
\hline 46. & Sodium salicylate & Salicylan sodowy & 2 & 4 \\
\hline 47. & Talc & Talk & 2 & 4 \\
\hline 48. & Benzyl salicylate & Salicylan benzylu & 1 & 2 \\
\hline 49. & Butylphenyl methylpropional & $\begin{array}{l}\text { Aldehyd 2-(4-tert-butylobenzy- } \\
\text { lo) propionowy }\end{array}$ & 1 & 2 \\
\hline 50. & Chlorhexidine digluconate & Diglukonin chlorheksydyny & 1 & 2 \\
\hline 51. & Ethylhexyl triazone & Etyloheksylotriazon & 1 & 2 \\
\hline 52. & Hexyl cinnamal & Aldehyd heksylocynamonowy & 1 & 2 \\
\hline 53. & Hydroxycitronellal & Hydroksycytronellal & 1 & 2 \\
\hline 54. & $\begin{array}{l}\text { Hydroxyisohexyl 3-cyclohexe- } \\
\text { ne carboxaldehyde }\end{array}$ & $\begin{array}{l}\text { Karboksyaldehyd hydroksyizo- } \\
\text { heksylo3-cykloheksenu }\end{array}$ & 1 & 2 \\
\hline 55. & Iodopropynyl butylcarbamate & $\begin{array}{l}\text { Butylokarbaminian jodopro- } \\
\text { pynylu }\end{array}$ & 1 & 2 \\
\hline 56. & Zinc lactate & Mleczan cynku & 1 & 2 \\
\hline 57. & Zinc sulfate & Siarczan cynku & 1 & 2 \\
\hline 58. & CI 61570 & CI 61570 (barwnik zielony) & 1 & 2 \\
\hline 59. & CI 17200 & CI 17200 (barwnik czerwony) & 1 & 2 \\
\hline
\end{tabular}


Co najmniej jedna substancja aktywna występowała w $100 \%$ analizowanych produktów. Liczba składników aktywnych w pojedynczym produkcie mieściła się $\mathrm{w}$ przedziale od 1 do 11 . Zaledwie 18 produktów (36\%) zawierało składniki aktywne skierowane przeciw wszystkim kluczowym elementom patogenezy trądziku, co wydaje się najbardziej efektywną strategią. Liczba substancji „,problematycznych” w poszczególnych produktach wahała się od 0 do 12 . Wartość współczynnika korelacji między ilością składników aktywnych i ,problematycznych" wyniosła 0,45 , co można ocenić jako wskaźnik przeciętnej korelacji.

\section{Dyskusja}

W niniejszej pracy substancją aktywną najczęściej stosowaną przed producentów kosmetyków przeciwtrądzikowych okazał się kwas salicylowy, głównie ze względu na jego właściwości keratolityczne oraz efekty przeciwzapalne na skutek blokowania tworzącej mediatory zapalne cyklooksygenazy kwasu arachidonowego $[8,9]$. Wykorzystuje się ponadto właściwości piroglutaminianu cynku, który ma hamować aktywność 5-alfa reduktazy - enzymu przekształcającego testosteron w silnie stymulujący gruczoły łojowe dihydroksytestosteron [10]. Także nikotynamid był szeroko stosowany przez producentów kosmetyków przeciwtrądzikowych. Randomizowane badania 76 osób z umiarkowanie ciężkim trądzikiem wykazały, że ośmiotygodniowa terapia żelem z dodatkiem 4\% nikotynamidu jest równie skuteczna jak terapia 1\% żelem klindamycyny [11]. Wyniki analizy pokazały ponadto szerokie wykorzystanie składników naturalnych w kosmetykach przeciwtrądzikowych, najczęściej aloesu zwyczajnego oraz olejku z drzewa herbacianego. W badaniach 60 pacjentów olejek z drzewa herbacianego spowodował istotne zmniejszenie liczby zmian trądzikowych oraz nasilenia trądziku [12]. Jednak olejek drzewa herbacianego może również powodować alergiczny wyprysk kontaktowy [13].

Kolejnym istotnym punktem w niniejszej pracy była analiza obecności substancji potencjalnie niebezpiecznych w deklarowanym przez producenta składzie kosmetyku. W opisach analizowanych produktów nie było substancji wymienianych w Liście substancji zakazanych do użycia w kosmetykach (List of substances prohibited in cosmetics product) zawartej w Aneksach do Dyrektywy Kosmetycznej 76, stosunkowo często występowały jednak substancje ,problematyczne”, wymieniane jako potencjalnie niebezpieczne w Aneksach do Dyrektywy Kosmetycznej. Substancje ,problematyczne” były obecne $98 \%$ produktów, a mnogość takich substancji w pojedynczych produktach budzi niepokój. Najczęściej stosowaną substancją ,problematyczną” okazał się fenoksyetanol, konserwant który może powodować alergiczne kontaktowe zapalenie skóry, a także pokrzywkę
[14]. W analizowanych produktach często wykorzystywano także właściwości konserwujące parabenów, które mogą uczulać - szczególnie w obecności stanu zapalnego [15]. Wyniki testów płatkowych ze środkami konserwującymi u 1927 osób wykazały, iż parabeny powodują stosunkowo najmniej reakcji alergicznych $(0,3 \%)$ [16], jednak nie można wykluczyć, że ich właściwości alergizujące mogą się kumulować [17]. W ciągu dnia przeciętny człowiek wykorzystuje wiele różnych kosmetyków, takich jak pasty, szampony, żele, kremy, itp. Około 90\% produktów kosmetycznych zawiera 1 lub więcej parabenów, przez co wysoce prawdopodobna wydaje się kumulacja tych substancji w skórze [18]. Niestety w ramach niniejszych analiz, opartych na podanych przez producentów informacji o składzie kosmetyków, nie była możliwa ocena stężeń substancji w poszczególnych produktach, co zmniejsza precyzję oceny ryzyka.

Substancje aktywne stosowane przez producentów w analizowanych kosmetykach przeciwtrądzikowych sprzedawanych w aptekach faktycznie mogą przyczynić się do poprawy kondycji skóry trądzikowej. Niemniej jednak porównanie wyników niniejszej analizy z opartym na tej samej metodologii badaniem 50 kosmetyków przeciwtrądzikowych dostępnych w drogeriach [19] wskazuje, że wprawdzie liczba wszystkich składników, a także substancji aktywnych była wyższa w preparatach przeciwtrądzikowych sprzedawanych w aptece, jednak zawierały one równie więcej substancji ,,problematycznych”, czyli składników o znanym potencjale uczulającym. Obserwacja ta sugeruje, że sprzedawane w aptece kosmetyki przeciwtrądzikowe mogą być bardziej skuteczne, ale jednocześnie mniej bezpieczne od swoich drogeryjnych odpowiedników. Potwierdza to wyniki wcześniejszych analiz składu emolientów, czyli kosmetyków do pielęgnacji skóry chorej na wyprysk: spośród 177 emolientów sprzedawanych w aptekach, zaledwie 37 (21\%) było wolne od składników o znanym potencjale uczulającym z aneksów III i VI europejskiej Dyrektywy Kosmetycznej [20].

\section{Wnioski}

1. Kompleksowym działaniem przeciwtrądzikowym, rozumianym jako obecność $\mathrm{w}$ preparacie składników skierowanych przeciw wszystkim znanym aktualnie elementom łańcucha przyczynowo-skutkowego w trądziku cechuje się zaledwie jedna trzecia sprzedawanych w aptekach kosmetyków przeciwtrądzikowych.

2. Do substancji aktywnych najczęściej dodawanych do kosmetyków przeciwtrądzikowych sprzedawanych w aptekach należą kwas salicylowy, alantoina oraz piroglutaminian cynku - składniki szeroko stosowane także w pospolitych produktach kosmetycznych. 
3. Prawie wszystkie kosmetyki przeciwtrądzikowe sprzedawane w aptekach zawierają składniki ,problematyczne", najczęściej fenoksyetanol oraz parabeny.

\section{Piśmiennictwo}

1. Sidbury R, Paller AS: The diagnosis and management of acne. Ped Annals 2000; 29: 17-24.

2. Webster GF, Rawlings AV: Biologia gruczołu łojowego i patofizjologia trądziku. Przegląd wiedzy na temat patogenezy trądziku. W: Trądzik Diagnostyka i leczenie. Wydawnictwo Czelej, Lublin 2009: 1.

3. Bhambri S, Del Rosso JQ, Bhambri A: Pathogenesis of acne vulgaris: recent advances. J Drugs Dermatol. 2009; 8(7):615-618.

4. Czarnecka-Operacz M, Jakubowicz O: Rola zabiegów pielęgnacyjnych w leczeniu trądziku. Przegl Dermatol 2010; 97:335-341.

5. Fink E: Substancje czynne i pomocnicze w kosmetyce W: Kosmetyka. Przewodnik po substancjach czynnych i pomocniczych. MedPharm, Wrocław 2007: 108-220.

6. Personal Care Products Council: What is INCI? URL: http://www.personalcarecouncil.org/science-safety/ what-inci (dokument elektroniczny, stan na dzień 03.07.2012)

7. Arct J, Pytkowska K, Barska K, Kifert K, Pauwels A: Leksykon surowców kosmetycznych. Wydawnictwo Wyższej Szkoły Zawodowej Kosmetyki i Pielęgnacji Zdrowia w Warszawie, Warszawa 2010: 15-240.

8. Akhavan A, Bershad S: Topical Acne Drugs. Review of Clinical Properties, Systemic Exposure, and Safety. Am J Clin Dermatol 2003; 4(7): 473-492.

9. Placek W, Romańska-Gocka K, Grzanka A: Leczenie miejscowe trądziku. Przegl Dermatol 2011; 98: 442-448.

10. Szpanka J: Surowce do zadań specjalnych. Przemysł Kosmetyczny 2011; 2: 36-39.

11. Shalita AR, Smith G, Parish LC, Sofman MS, Chalker DK: Topical Nicotinamide compared with Clindamycin gel in the treatment of inflammatory acne vulgaris. Int J Dermatol 1995; 34(6): 434-437.

12. Enshaieh S, Jooya A, Siadat AH, Iraji F: The efficacy of $5 \%$ topical tea tree oil gel in mild to moderate acne vulgaris: A randomized, double-blind placebo-controlled study. Indian J Dermatol Venereol Leprol 2007; 73: 20-25.

13. Rutherford T, Nixon R, Tam M, Tate B: Allergy to tea tree oil: Retrospective review of 41 cases with positive patch tests over 4,5 years. Australas J Dermatol 2007; 48: 83-87.

14. Kieć-Świerczyńska M, Kręcisz B, Świerczyńska-Machura D: Uczulenie na kosmetyki. II. Środki konserwujące. Med Pracy 2004; 55(3): 289-292.

15. Bojarowicz H, Wojciechowska M, Gocki J: Substancje konserwujące stosowane w kosmetykach oraz ich działanie niepożądane. Probl Hig Epidemiol 2008; 89(1): 30-33.

16. Kieć-Świerczyńska M, Kręcisz B, Świerczyńska-Machura D: Uczulenie kontaktowe na środki konserwujące zawarte w kosmetykach. Med Pracy 2006; 57(3): 245-249.

17. Wojciechowska M, Kołodziejczyk J, Mućka J, Gocki J, Bartuzi Z: Występowanie objawów ubocznych i alergii na wybrane składniki kosmetyków u osób z chorobami alergicznymi. Post Dermatol Alergol 2010; 6: 456-459.
18. Sawsan EH, Muret P, Berard M, Makki S, Humbert P: Assessment of principal parabens used in cosmetics after their passage through human epidermis-dermis layers (ex-vivo study). Exp Dermatol 2007; 16:830-836.

19. Macioł M, Kordus K, Śpiewak R: Kosmetyki do cery trądzikowej dostępne w handlu detalicznym: Analiza deklarowanych składników aktywnych oraz substancji potencjalnie niebezpiecznych. Estetol Med Kosmetol 2012; 2(3):83-88.

20. Kordus K, Śpiewak R: Emolienty z apteki - pomoc czy zagrożenie dla chorych na wyprysk? Alergia Astma Immunologia 2012;17(3):147-153.

\section{Finansowanie i konflikt interesów}

Dane przedstawione w niniejszej pracy zostały zebrane przez Sabinę Rzeźnik w ramach pracy magisterskiej pt. ,Kosmeceutyki" $i$,,dermokosmetyki” do cery tradzikowej. Analiza deklarowanych składników aktywnych oraz substancji potencjalnie niebezpiecznych $w$ losowej próbie produktów dostęnych w aptekach (promotor: Radosław Śpiewak, opiekun: Katarzyna Kordus) obronionej na Wydziale Farmaceutycznym UJ. Autorzy deklarują niewystępowanie konfliktu interesów w odniesieniu do treści zawartych w niniejszej pracy.

\section{Adres do korespondencji}

dr hab. med. Radosław Śpiewak, profesor UJ Zakład Dermatologii Doświadczalnej i Kosmetologii Wydział Farmaceutyczny UJ ul. Medyczna 9, 30-688 Kraków Tel.: 1262058 30, Fax: 126205645 E-mail: spiewak.eu@gmail.com

Data złożenia: 17.07 .2012

Data akceptacji: 18.09.2012 